\title{
PENGARUH PEMANFAATAN FLY ASH PADA BETON RINGAN FOAM UNTUK DINDING PARTISI TERHADAP KUAT TEKAN, BERAT JENIS DAN DAYA SERAP AIR
}

\author{
Apriadi Prmausyagi ${ }^{1}$, Chundakus Habsya ${ }^{2}$, Sri Sumarni $^{3}$ \\ Pendidikan Teknik Bangunan, Universitas Sebelas Maret \\ e-mail : apriadi_55@ymail.com
}

\begin{abstract}
Abstrak
Tujuan penelitian adalah, (1) mengetahui pengaruh fly ash sebagai pengganti sebagian agregat halus dan variasi foam terhadap kuat tekan bata beton ringan foam, (2) mengetahui pengaruh fly ash sebagai pengganti sebagian agregat halus dan variasi foam terhadap berat jenis bata beton ringan foam, (3) mengetahui pengaruh fly ash sebagai pengganti sebagian agregat halus dan variasi foam terhadap daya serap air bata beton ringan foam, (4) mengetahui persentase fly ash sebagai pengganti sebagian agregat halus dan variasi foam untuk mencapai kuat tekan yang memenuhi SNI 03-0349-1989, (5) mengetahui persentase fly ash sebagai pengganti sebagian agregat halus dan varisi foam untuk mecapai berat jenis beton ringan yang memenuhi SNI 03-2847-2002, (6) mengetahui persentase fly ash sebagai pengganti sebagian agregat halus dan variasi foam untuk mencapai daya serap air yang memenuhi SNI 03-0349-1989. Penelitian ini menggunakan metode kuantitatif eksperimen dan teknik analisa data menggunakan analisis regresi. Variabel yang mempengaruhi dalam penelitian adalah (1) variabel terikat: kuat tekan, berat jenis, dan daya serap air bata beton ringan foam, (2) variabel bebas: pengganti sebagian agregat halus dengan fly ash dengan variasi $0 \%, 15 \%, 30 \%, 45 \%$, dan $60 \%$ dan variasi foam $50 \%$ dan $70 \%$ dari volume beton. Berdasarkan hasil penelitian disimpulkan bahwa, (1) variasi fly ash dan variasi foam $50 \%$ berpengaruh $77,6 \%$, pada variasi foam $70 \%$ berpengaruh $77,1 \%$ terhadap kuat tekan bata beton ringan foam, (2) variasi fly ash dan variasi foam $50 \%$ berpengaruh $92 \%$, pada variasi foam $70 \%$ berpengaruh $88,3 \%$ terhadap berat jenis bata beton ringan foam, (3) variasi fly ash dan variasi foam $50 \%$ berpengaruh $92,4 \%$, pada variasi foam $70 \%$ berpengaruh $43,3 \%$ terhadap daya serap air bata beton ringan foam, (4) tidak didapatkan persentase $f l y$ ash dan variasi foam untuk mencapai kuat tekan yang memenuhi SNI 03-03491989 pada foam 50\% terdapat kuat tekan optimal 1,825 MPa dengan fly ash $35,52 \%$ dan foam $70 \%$ terdapat kuat tekan optimal 0,541 MPa dengan fly ash $27,54 \%$, (5) Semua persentase fly ash dan variasi foam menghasilkan nilai berat jenis beton ringan yang memenuhi SNI 03-2847-2002 dengan nilai minimal berat jenis $561,185 \mathrm{~kg} / \mathrm{m}^{3}$ dengan variasi fly ash $56,19 \%$, (6) Persentase fly ash dan variasi foam menghasilkan nilai daya serap air yang memenuhi SNI 03-03491989 terdapat pada nilai optimal 23,583\% dengan variasi fly ash 28,52\% dan foam $50 \%$.
\end{abstract}

Kata kunci: fly ash, bata beton ringan foam, kuat tekan, berat jenis, daya serap air

${ }^{1}$ Mahasiswa Program Studi Pendidikan Teknik Bangunan FKIP UNS.

${ }^{2}$ Pembimbing I Ir. Chundakus Habsya MS.Ars.

${ }^{3}$ Pembimbing II Sri Sumarni S.T., M.T. 


\begin{abstract}
The purposes of this research were to, (1) determine the effect of fly ash as smooth replacement of fine aggregate and foam variation of compressive strength lightweight foam concrete brick, (2) determine the effect of fly ash as smooth replacement of fine aggregate and foam variation of density lightweight foam concrete brick, (3) determine the effect of fly ash as smooth replacement of fine aggregate and foam variation of water absorbtion lightweight foam concrete brick, (4) determine the percentage of fly ash as smooth aggregate partial substitute and foam variation to achieve the compressive strength which fulfilled SNI 03-0349-1989, (5) determine the percentage of fly ash as smooth aggregate partial substitute and foam variation to achieve the density lightweight concrete which fulfilled SNI 03-2847-2002, (6) determine the percentage of fly ash as smooth aggregate partial substitute and foam variation to achieve the water absorbtion which fulfilled SNI 03 -0349-1989. This research used experimental method and data analysis techniques regression analysis. Variables in the study were (1) dependent variables: compressive strength, density, and water absorbtion of lightweight foam concrete bricks, (2) independent variables: the substitute of smooth aggregate to fly ash with variation 0\%, 15\%, 30\%, 45\% and $60 \%$ and foam variation $50 \%$ and $70 \%$ of concrete volume. Based on the results of the study concluded that, (1) variation fly ash and variation foam 50\% was $77,6 \%$ influence, to variation foam $70 \%$ was $77,1 \%$ influence towards the compressive strength of lightweight foam concrete bricks, (2) variation fly ash and variation foam $50 \%$ was $92 \%$ influence, to variation foam $70 \%$ was $88,3 \%$ influence towards the density of lightweight foam concrete bricks, (3) variation fly ash and variation foam $50 \%$ was $92,4 \%$ influence, to variation foam $70 \%$ was $43,3 \%$ influence towards the water absorbtion of lightweight foam concrete bricks, (4) determine the percentage of fly ash as smooth aggregate partial substitute and foam variation to achieve the compressive strength which fulfilled SNI 03-0349-1989 to 50\% foam there are compressive strength of 1,825 MPa with 35,52\% fly ash and 70\% foam there are compressive strength of 0,541 $\mathrm{MPa}$ with 27,54\% fly ash, (5) All percentages of fly ash and foam variation produced the density value of lightweight foam concrete brick which fulfilled SNI 03 -28472002 with a minimum value density of $561,185 \mathrm{~kg} / \mathrm{m}^{3}$ with a variation fly ash $56,19 \%$, (6) the percentage of fly ash and variation foam produce water absorbtion values which fulfilled SNI 03-0349-1989 there in optimal 23,583\% with value variation fly ash $28,52 \%$ and foam $50 \%$.
\end{abstract}

Keywords: fly ash, lightweight foam concrete bricks, compressive strength, density, water absorbtion.

\footnotetext{
${ }^{1}$ Mahasiswa Program Studi Pendidikan Teknik Bangunan FKIP UNS.

${ }^{2}$ Pembimbing I Ir. Chundakus Habsya MS.Ars.

${ }^{3}$ Pembimbing II Sri Sumarni S.T., M.T.
} 


\section{PENDAHULUAN}

\section{a. Latar Belakang Masalah}

Perkembangan pendidikan dan teknologi yang pesat saat ini membawa perubahan di kehidupan terutama pada bidang pembangunan. Mutu dan teknologi bahan bangunan telah mengalami kemajuan berkat adanya penelitian terus menerus. Hal ini menyebabkan beton menjadi bahan bangunan yang popular dalam dunia konstruksi karena material yang mudah didapat, mudah dibentuk ataupun dicetak sesuai dengan keinginan.

Beton ringan adalah beton yang mengandung agregat ringan dan mempunyai berat satuan dengan kepadatan lebih kecil dari 1900 kg/m (SNI-03-2847-2002) Penggunaan beton ringan pada konstruksi bangunan bertingkat dapat mengurangi berat bangunan itu sendiri, yang selanjutnya berdampak pada perhitungan pondasi serta dimensi komponen struktur.

Abu terbang (fly ash) dengan sifat pozzolan yang cukup bagus digunakan sebagai bahan campuran untuk mengisi rongga udara dalam beton sehingga bisa mendapatkan beton mutu tinggi. Pemanfaatan abu terbang (fly ash) sebagai bahan bangunan dapat secara langsung mengurangi penimbunan limbah yang bersifat B3.

Pada penelitian Susmiati (2015), campuran 1 pc : 4 agregat halus dengan abu terbang (fly ash) dimanfaatkan sebagai bahan pengganti sebagian agregat halus bata beton ringan foam dengan variasi abu terbang (fly ash) 0\%, 25\%, 50\% dan $75 \%$ dan perbandingan 1 foam agent : 40 air dengan variasi foam $20 \%$ dan $40 \%$. Didapatkan persentase optimal sebesar $50 \%$ abu terbang (fly ash) dan $20 \%$ foam dengan kuat tekan maksimal 6,196 Mpa yang memenuhi karakteristik bata beton pejal yang tegolong mutu III dalam SNI No. 030349-1989 sedangkan persentase 75\% abu terbang (fly ash) dan $40 \%$ foam menghasilkan kuat tekan maksilmal 2,479 Mpa yang belum memenuhi karakteristik mutu bata beton pejal kuat tekan tersebut masih belum memenuhi standart SNI No.

${ }^{1}$ Mahasiswa Program Studi Pendidikan Teknik Bangunan FKIP UNS.

${ }^{2}$ Pembimbing I Ir. Chundakus Habsya MS.Ars.

${ }^{3}$ Pembimbing II Sri Sumarni S.T., M.T. 
03-0349-1989. Disini peneliti melanjutkan penelitian yang sama dengan beberapa variasi yang berbeda.

\section{b. Tujuan Penelitian}

Tujuan penelitian sebagai berikut :

1) Untuk mengetahui pengaruh abu terbang (fly ash) sebagai pengganti sebagian agregat halus terhadap kuat tekan beton ringan foam.

2) Untuk mengetahui pengaruh abu terbang (fly ash) sebagai pengganti sebagian agregat halus terhadap berat jenis beton ringan foam.

3) Untuk mengetahui pengaruh abu terbang (fly ash) sebagai pengganti sebagian agregat halus terhadap daya serap air beton ringan foam.

4) Untuk mengetahui persentase penggantian abu terbang (fly ash) untuk mencapai kuat tekan maksimal pada beton ringan foam.

5) Untuk mengetahui persentase penggantian abu terbang (fly ash) untuk mencapai berat jenis minimal pada beton ringan foam.

6) Untuk mengetahui persentase penggantian abu terbang (fly ash) untuk mencapai daya serap air minimal pada beton ringan foam.

\section{c. Kajian Pustaka}

\section{1) Bata Ringan/Bata Beton}

\section{Ringan}

Beton ringan adalah beton yang mengandung agregat ringan dan mempunyai berat satuan dengan kepadatan lebih kecil dari $1900 \mathrm{~kg} / \mathrm{m}^{3}$ (SNI-03-2847-2002). Beton ringan bukan saja diperhitungkan karena beratnya yang ringan, tetapi juga karena isolasi suhu yang tinggi dibandingkan beton biasa, umumnya pengurangan kepadatan diikuti dengan kenaikan isolasi suhu meskipun terjadi penurunan kekuatan (Murdock, 1986). Beton ringan juga memiliki keuntungan, yaitu: memiliki tahan panas yang baik, memiliki tahan suara yang baik (peredam suara), tahan api. Sedangkan kelemahan beton ringan yaitu: nilai kuat tekan yang kecil dibanding beton normal sehingga tidak dianjurkan untuk struktural (Sumarno, 2010).

Berdasarkan SNI No. 03-03491989 syarat fisis bata beton untuk

${ }^{1}$ Mahasiswa Program Studi Pendidikan Teknik Bangunan FKIP UNS

${ }^{2}$ Pembimbing I Ir. Chundakus Habsya MS.Ars.

${ }^{3}$ Pembimbing II Sri Sumarni S.T., M.T. 
pasangan dinding dapat dilihat pada tabel 1 .

Tabel 1. Syarat Fisis Bata Beton Untuk Pasangan Dinding

\begin{tabular}{|c|c|c|c|c|c|}
\hline \multirow[t]{2}{*}{ Syarat Fisis } & \multirow[t]{2}{*}{ Satuan } & \multicolumn{4}{|c|}{$\begin{array}{c}\text { Tingkat mutu bata } \\
\text { beton pejal }\end{array}$} \\
\hline & & $\mathrm{I}$ & II & III & IV \\
\hline $\begin{array}{l}\text { Kuat tekan } \\
\text { bruto rata- } \\
\text { rata minimal }\end{array}$ & $\mathrm{kg} / \mathrm{cm}^{2}$ & 100 & 70 & 40 & 25 \\
\hline $\begin{array}{c}\text { Kuat tekan } \\
\text { benda bruto } \\
\text { masing- } \\
\text { masing } \\
\text { benda uji } \\
\text { minimal }\end{array}$ & $\mathrm{kg} / \mathrm{cm}^{2}$ & 90 & 65 & 35 & 21 \\
\hline $\begin{array}{c}\text { Penyerapan } \\
\text { air rata- rata } \\
\text { maksimal }\end{array}$ & $\%$ & 25 & 35 & -- & -- \\
\hline
\end{tabular}

2) Bahan Penyusun Bata Beton Ringan Foam dengan Bahan Tambah Abu Terbang (fly ash)

Perancangan campuran bata beton ringan foam menggunakan acuan kebutuhan bahan berdasarkan Road Note No.4. Pada tahap ini, kebutuhan bahan dilakukan setelah tahap kedua. Pada penelitian susmiati (2015) menggunakan foam 20\% denagn fly ash 50\% menghasilkan kuat tekan terbesar 6,196 dan foam 40\% dengan fly ash 75\% menghasilkan kuat tekan terbesar 2,478 Mpa, dengan perbandingan $1 \mathrm{pc}: 4$ agregat halus
Mpa. Dan hanizam awang (2012) menggunakan fly ash 15\% mengahasilakan kuat tekan 3,1 Mpa dan fly ash 30\% menghasilkan 3,2 Mpa, dengan perbandingan $1 \mathrm{pc}: 1,5$ pasir : 0,45 air menghasilkan kuat tekan sebesar 3,1 $\mathrm{MPa}$ pada berat beton ringan $1000 \mathrm{~kg} / \mathrm{m}^{2}$. Dari perbandingan diatas penelitian ini menggunakan foam $50 \%$ dan $70 \%$ dengan fly ash 0\%, 15\%, 30\%, 45\% dan $60 \%$ perancangan perbandingan 1 pc : 1 agregat

\section{3) Foam agent}

Foam agent adalah suatu larutan pekat dari bahan surfaktan, dimana apabila hendak digunakan harus dilarutkan dengan air. Dengan membuat gelembung - gelembung gas/udara dalam adukan semen, dengan demikian akan terjadi banyak pori - pori udara di dalam betonnya (Muhammad Afaza, 2014).

\section{4) Additive Foam Concrete}

Additive foam concrete adalah bahan campuran untuk pekerjaan pembuatan bata ringan membuat foam lebih stabil, mempercepat pengerasan, dan juga menambah kuat tekan.

${ }^{1}$ Mahasiswa Program Studi Pendidikan Teknik Bangunan FKIP UNS.

${ }^{2}$ Pembimbing I Ir. Chundakus Habsya MS.Ars.

${ }^{3}$ Pembimbing II Sri Sumarni S.T., M.T. 


\section{5) Abu Terbang (fly ash)}

Abu terbang (fly ash) berupa butiran halus ringan, tidak porous, dan bersifat pozzolanik. Abu terbang tidak memiliki kemampuan mengikat seperti semen tapi dengan adanya air dan partikel ukuran halus, oksida silika yang terkandung di dalamnya akan bereaksi secara kimia dengan kalsium hidroksida yang terbentuk dari proses hidrasi semen dan menghasilkan zat yang memiliki kemampuan mengikat (Krisbiyantoro, 2005).

Sebagian besar komponen kimia dari abu terbang tergantung tipe batu bara, menurut ASTM C618-86 dalam Eko Hindaryanto, 2010, terdapat dua jenis abu terbang kelas F dan C. Kelas F dihasilkan dari pembakaran batu bara jenis antrasit dan bituminous, sedangkan kelas $\mathrm{C}$ dari batu bara jenis lignite dan subituminous. Ada perbedaan warna dari fly as tipe $\mathrm{F}$ dan $\mathrm{C}$, dari tipe $\mathrm{F}$ berwarna abu-abu gelap sedangkan tipe $\mathrm{C}$ berwarna kecoklatan.

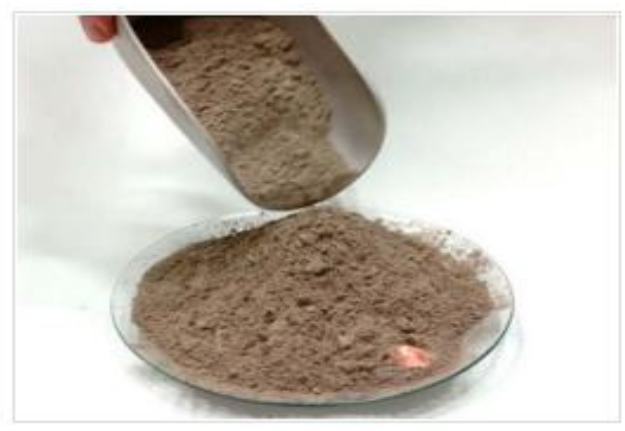

Gambar 1. Fly ash Tepe F

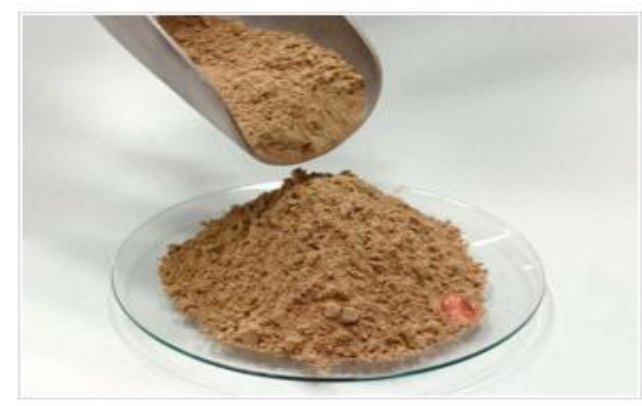

Gambar 2. Fly ash Tipe C

Kandungan kimia yang ada dalam fly ash tercantum dalam tabel 2 . (ASTM C618-950)

Tabel 2. Kandungan kimia fly ash

\begin{tabular}{|c|c|c|}
\hline Senyawa Kimia & $\begin{array}{l}\text { Jenis } \\
\text { F }\end{array}$ & $\begin{array}{l}\text { Jenis } \\
\text { C }\end{array}$ \\
\hline $\begin{array}{l}\text { Oksida Silika }\left(\mathrm{SiO}_{2}\right) \\
+ \text { Oksida Alumina } \\
\left(\mathrm{AI}_{2} \mathrm{O}_{3}\right)+\mathrm{Oksida} \\
\mathrm{Besi}\left(\mathrm{Fe}_{2} \mathrm{O}_{3}\right), \\
\text { minimum \% }\end{array}$ & 70.0 & 50.0 \\
\hline $\begin{array}{l}\text { Trioksida Sulfur } \\
\left(\mathrm{SO}_{3}\right), \text { maksimum \% }\end{array}$ & 5.0 & 5.0 \\
\hline $\begin{array}{ll}\text { Kadar } & \text { Air, } \\
\text { maksimum \% } & \\
\end{array}$ & 3.0 & 3.0 \\
\hline $\begin{array}{l}\text { Kehilangan Panas, } \\
\text { maksimum } \%\end{array}$ & 6.0 & 6.0 \\
\hline
\end{tabular}

${ }^{1}$ Mahasiswa Program Studi Pendidikan Teknik Bangunan FKIP UNS

${ }^{2}$ Pembimbing I Ir. Chundakus Habsya MS.Ars.

${ }^{3}$ Pembimbing II Sri Sumarni S.T., M.T. 


\section{6) Pengujian}

\section{1) Kuat Tekan}

Salah satu sifat penting dari beton ringan adalah kuat tekannya yang dapat digunakan sebagai dasar dalam penilaian mutu atau karakteristik dari produk beton yang dihasilkan. Besarnya kuat tekan beton dapat dihitung dengan rumus sebagai berikut:

$\mathrm{P}=\frac{F}{A}$

Dimana :

$\mathrm{P}=$ kuat tekan $\left(\mathrm{N} / \mathrm{mm}^{2}\right)$

$\mathrm{F}=$ beban tekan maksimum $(\mathrm{N})$

$\mathrm{A}=$ luas penampang benda uji yang ditekan $\left(\mathrm{mm}^{2}\right)$

\section{2) Berat Jenis}

Pengujian berat jenis beton dilakukan dengan menggunakan pengukuran berat dan volume.

Adapun perhitungan yang dirumuskan sebagai berikut:

$\mathrm{BJ}=\frac{W}{V}$

Dimana :

$\mathrm{BJ}=$ berat jenis $\left(\mathrm{gr} / \mathrm{cm}^{3}\right)$

$\mathrm{W}=$ berat benda uji (gram)

$\mathrm{V}=$ volume benda uji $\left(\mathrm{cm}^{3}\right)$

\section{3) Daya Serap Air}

Daya serap air adalah kemampuan beton ringan untuk menyerap air ketika dalam air hingga memiliki massa jenuh. Berdasarkan Kardiyono Tjokrodimuljo (1996) dalam Helmi Ardiansyah (2004), besarnya serapan air pada beton dapat dirumuskan sebagai berikut:

$\mathrm{WA}=\frac{\mathrm{mj}-\mathrm{mk}}{\mathrm{mk}} \times 100 \%$

Dimana:

$\mathrm{WA}=$ daya serap air $(\%)$

$\mathrm{mj}$ = massa benda jenuh $(\mathrm{kg})$

$\mathrm{mk}=$ massa benda kering $(\mathrm{kg})$

\section{METODOLOGI PENELITIAN}

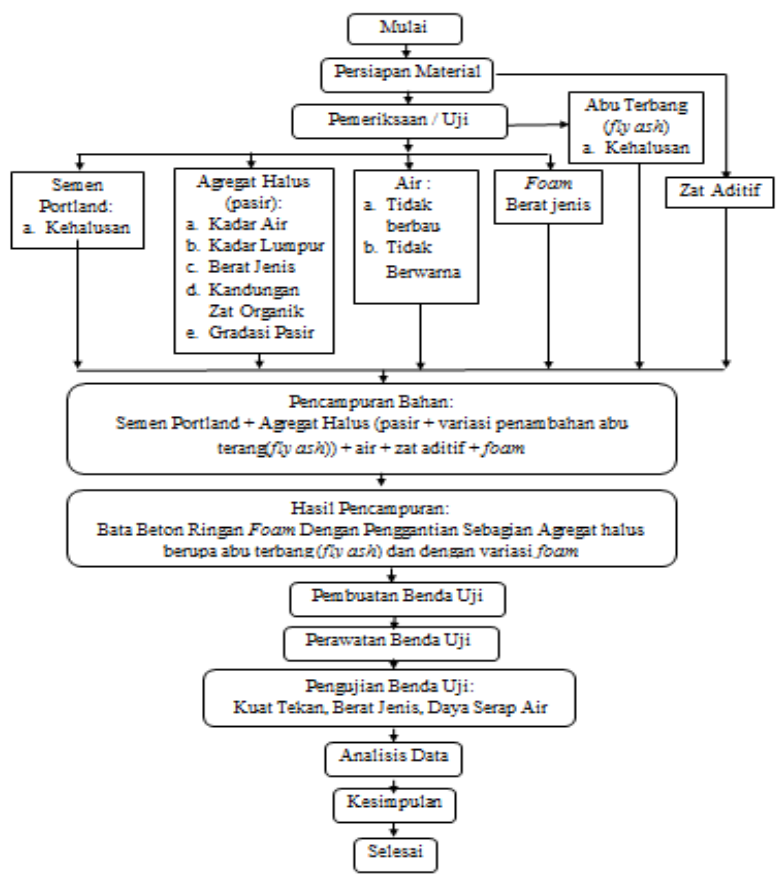

Gambar 3. Alur Penelitian

${ }^{1}$ Mahasiswa Program Studi Pendidikan Teknik Bangunan FKIP UNS.

${ }^{2}$ Pembimbing I Ir. Chundakus Habsya MS.Ars.

${ }^{3}$ Pembimbing II Sri Sumarni S.T., M.T. 


\section{a. Tahap Pertama}

Pada tahap ini seluruh bahan dan peralatan yang dibutuhkan dalam penelitian dipersiapkan terlebih dahulu agar penelitian dapat berjalan dengan lancar.

\section{b. Tahap Kedua}

Pada tahap ini dilakukan pengujian terhadap material penyusun bata beton ringan. Hal ini dilakukan untuk mengetahui sifat dan karakteristik bahan.

\section{c. Tahap Ketiga}

Disebut tahap rencana campuran (mix design) Perancangan campuran bata beton ringan foam menggunakan acuan kebutuhan bahan berdasarkan Road Note No.4.Pada tahap ini, kebutuhan bahan dilakukan setelah tahap kedua.

\section{d. Tahap Keempat}

Disebut tahap pembuatan benda uji. Pada tahap ini dilakukan persiapan bahan penyusun bata beton ringan foam, dan perawatan.

\section{e. Tahap Kelima}

Pada tahap ini dilakukan pengujian kuat tekan, berat jenis dan daya serap air.

\section{f. Tahap Keenam}

Tahap analisa data dan pembahasan.

\section{g. Tahap Ketujuh}

Tahap ini berupa penarikan kesimpulan.

\section{HASIL DAN PEMBAHASAN}

\section{a. Pemeriksaan Pasir}

Pengujian agregat halus (pasir) dalam penelitian ini meliputi kadar lumpur, kadar air, kadar zat organik, specific gravity dan gradasi. Hasil uji pengujian agregat dapat dilihat pada tabel 3 berikut :

Tabel 3. Hasil Pengujian Agregat Halus

\begin{tabular}{llll}
\hline $\begin{array}{l}\text { Uji } \\
\text { Bahan }\end{array}$ & Nilai & $\begin{array}{l}\text { Standa } \\
\mathrm{r}\end{array}$ & Keterangan \\
\hline Kadar & 2,3 & $<5 \%$ & $\begin{array}{l}\text { Memenuhi } \\
\text { persyaratan }\end{array}$ \\
Lumpur & $\%$ & & $\begin{array}{l}\text { Penggunaan } \\
\text { air dikurangi }\end{array}$ \\
\hline Kadar & 4,2 & $1-3 \%$ & Penurunan \\
Air & $\%$ & & kekuatan \\
\hline Kadar & $0-10$ & - & Termasuk \\
Zat & $\%$ & & $\begin{array}{l}\text { agregat halus } \\
\text { normal }\end{array}$ \\
Organik & & & $\begin{array}{l}\text { Masih dapat } \\
\text { digunakan }\end{array}$ \\
\hline $\begin{array}{l}\text { Specific } \\
\text { Gravity }\end{array}$ & 2,52 & $2,5-$ & 2,7 \\
SSD & & & \\
\hline Gradasi & Termasuk & \\
& daerah II &
\end{tabular}

\section{b. Pemeriksaan Fly ash}

Dalam pengujian hanya dilakukan pemeriksaan butirannya saja secara

\footnotetext{
${ }^{1}$ Mahasiswa Program Studi Pendidikan Teknik Bangunan FKIP UNS.

${ }^{2}$ Pembimbing I Ir. Chundakus Habsya MS.Ars.

${ }^{3}$ Pembimbing II Sri Sumarni S.T., M.T.
} 
visual untuk memastikan tidak ada butiran yang menggumpal. Adapun berat jenis fly ash yang berasal dari PLTU Tanjung Jati B Jepara yang didistribusikan oleh PT. Tiga Jaya Inti adalah sebesar 2,3 $\mathrm{g} / \mathrm{cm}^{3}$ (Laboratorium Bahan Jurusan Teknik Sipil FT UNS. Dalam Susmiati : 2015). Fly ash yang di pakai tipe F, karena karakteristik warna sama yang dijelaskan pada studi pustaka. Unsur kimia fly ash dapat dilihat pada tabel 4 berikut :

Tabel. 4. Unsur Kimia Fly ash

\begin{tabular}{|c|c|c|c|}
\hline \multicolumn{2}{|c|}{ Kode Contoh } & \multirow{2}{*}{$\begin{array}{c}\begin{array}{c}\text { Hasil } \\
\text { Analisis }\end{array} \\
54,42\end{array}$} & \\
\hline $\mathrm{SiO}_{2}$ & $\%$ & & Gravimetri \\
\hline $\mathrm{Fe}_{2} \mathrm{O}$ & $\%$ & 8,22 & AAS \\
\hline$\stackrel{3}{\mathrm{Al}_{2} \mathrm{O}}$ & $\%$ & 2,01 & AAS \\
\hline $\mathrm{CaO}$ & $\%$ & 16,78 & Titrimetri \\
\hline $\mathrm{SO}_{3}$ & $\%$ & 0,86 & $\begin{array}{l}\text { Spektrophot } \\
\text { ometri }\end{array}$ \\
\hline LOI & $\%$ & 1,45 & Gravimetri \\
\hline $\mathrm{H}_{2} \mathrm{O}$ & $\%$ & 0,37 & Gravimetri \\
\hline $\begin{array}{l}\text { Mes } \\
\text { h } \\
325\end{array}$ & $\begin{array}{l}\text { Tertah } \\
\text { an, } \% \\
\text { Lolos } \\
\%\end{array}$ & 13,80 & $\begin{array}{c}\text { Screen } \\
\text { ASTM E } \\
11-39\end{array}$ \\
\hline $\begin{array}{l}\text { (Labc } \\
\text { Kons } \\
\text { Kimi } \\
\text { susmi }\end{array}$ & $\begin{array}{l}\text { atorium } \\
\text { tasi In } \\
\text { FTI - } \\
\text { ti, } 2015\end{array}$ & $\begin{array}{l}\text { Team } \\
\text { tri Jur } \\
\text { S Sura }\end{array}$ & $\begin{array}{l}\text { liasi dan } \\
\text { in Teknik } \\
\text { ya, dalam }\end{array}$ \\
\hline
\end{tabular}

\section{c. Pemeriksaan Foam}

Berdasarkan hasil pemeriksaan berulang-ulang didapatkan nilai berat jenis foam rata-rata sebesar $87,4 \mathrm{~g} / \mathrm{l}$ dengan perbandingan 1 foam agent : 40 air.

\section{d. Hasil Pengujian Sampel}

Hasil pengujian kuat tekan, berat jenis, dan daya serap air bata beton ringan foam dengan fly ash sebagai pengganti sebagian agregat halus ditunjukkan pada tabel 5 :

Tabel 5. Hasil Pengujian

\begin{tabular}{ccccc}
\hline $\begin{array}{c}\text { Variasi } \\
\text { Foam }\end{array}$ & $\begin{array}{c}\text { Variasi } \\
\text { Abu } \\
\text { terbang }\end{array}$ & $\begin{array}{c}\text { Kuat } \\
\text { Tekan } \\
\text { Rata- } \\
\text { rata } \\
(\mathrm{MPa})\end{array}$ & $\begin{array}{c}\text { Berat } \\
\text { Jenis } \\
\text { Rata- } \\
\text { rata } \\
\left(\mathrm{kg} / \mathrm{m}^{3}\right)\end{array}$ & $\begin{array}{c}\text { Daya } \\
\text { Air } \\
(\%)\end{array}$ \\
\hline 0,5 & $0 \%$ & 0,274 & 962,858 & 41,911 \\
\hline 0,5 & $15 \%$ & 0,753 & 951,072 & 32,301 \\
\hline 0,5 & $30 \%$ & 2,241 & 917,263 & 23,107 \\
\hline 0,5 & $45 \%$ & 1,591 & 836,656 & 25,132 \\
\hline 0,5 & $60 \%$ & 0,987 & 811,067 & 32,462 \\
\hline 0,7 & $0 \%$ & 0,703 & 729,064 & 48,798 \\
\hline 0,7 & $15 \%$ & 0,536 & 649,815 & 36,012 \\
\hline 0,7 & $30 \%$ & 0,382 & 649,815 & 48,411 \\
\hline 0,7 & $45 \%$ & 0,616 & 567,153 & 30,562 \\
\hline 0,7 & $60 \%$ & 0,784 & 560,019 & 25,218 \\
\hline & & & & \\
\hline
\end{tabular}

\section{e. Pembahasan}

1) Persentase Penggantian Fly ash Yang Menghasilkan Kuat Tekan Optimal Bata Beton Ringan Foam

${ }^{1}$ Mahasiswa Program Studi Pendidikan Teknik Bangunan FKIP UNS.

${ }^{2}$ Pembimbing I Ir. Chundakus Habsya MS.Ars.

${ }^{3}$ Pembimbing II Sri Sumarni S.T., M.T. 


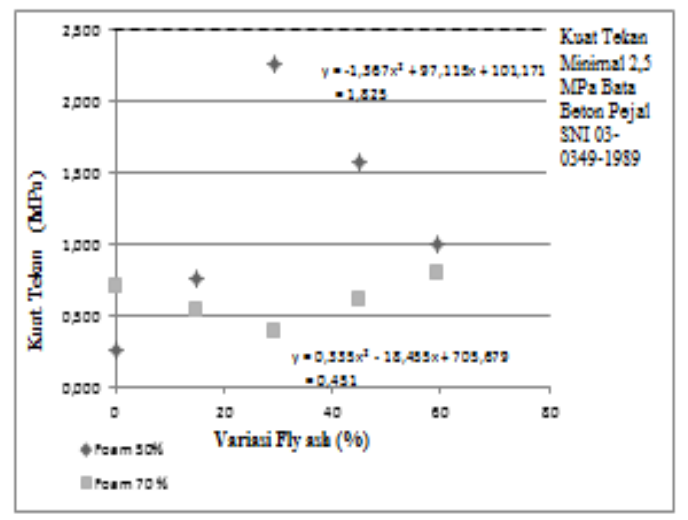

Gambar 4. Persyaratan Nilai Kuat Tekan Minimal Bata Beton Pejal Berdasarkan SNI 03-0349-1989

Penggunaan fly ash optimal untuk mencapai kuat tekan maksimal dengan variasi $0 \%, 15 \%, 30 \%, 45 \%$ dan $60 \%$ dengan nilai optimal pada penambahan foam 50\% penggantian fly ash 35,52\% dengan kuat tekan optimal 1,825 $\mathrm{MPa}$ dan foam $70 \%$ penggantian fly ash 27,54\% dengan kuat tekan optimal 0,451 MPa.

Semakin besar kadar fly ash maka kadar air yang dibutuhkan juga semakin bertambah, sehingga hal ini mempengaruhi nilai FAS yang mengakibatkan kuat tekan beton ringan foam mengalami penurunan saat melewati kadar fly ash $45 \%$ dan $60 \%$ pada variasi foam $50 \%$. Sedangkan pada variasi foam $70 \%$ terjadi penurunan pada kadar fly ash
$15 \%$ sampai $30 \%$. Hal ini dikarenakan komposisi fly ash yang berbeda dimana akan terjadi ikatan antara fly ash dan sisa hidrasi semen yang akan mengakibatkan porositas dan permeabilitas berkurang sehingga membuat beton lebih padat dan kuat. Pada variasi foam $50 \%$ terjadi peningkatan di variasi fly ash $15 \%$ $30 \%$ dan variasi $45 \%$ - $60 \%$ terjadi penurunan ini juga dikarenakan pencampuran air tiap variasi berbeda beda. Sedangkan pada variasi foam $70 \%$ terjadi penurunan pada variasi fly ash 15\% - 30\% dan variasi $45 \%$ $60 \%$ terjadi peningkatan dikarenakan pencampuran air tiap variasi berbeda - beda dan jumlah foam yang terlalu banyak.

Dari gambar 4 didapatkan persentase fly ash $30 \%$ dengan foam $50 \%$ yang menghasilkan nilai kuat tekan optimal 1,825 Mpa yang tidak memenuhi SNI 03 - 0349 - 1989 bata beton pejal. Dengan nilai kuat tekan minimal adalah 2,5 $\mathrm{MPa}$.

${ }^{1}$ Mahasiswa Program Studi Pendidikan Teknik Bangunan FKIP UNS

${ }^{2}$ Pembimbing I Ir. Chundakus Habsya MS.Ars.

${ }^{3}$ Pembimbing II Sri Sumarni S.T., M.T. 
2) Persentase Penggantian Fly ash Yang Menghasilkan Berat Jenis Optimal Bata Beton Ringan Foam

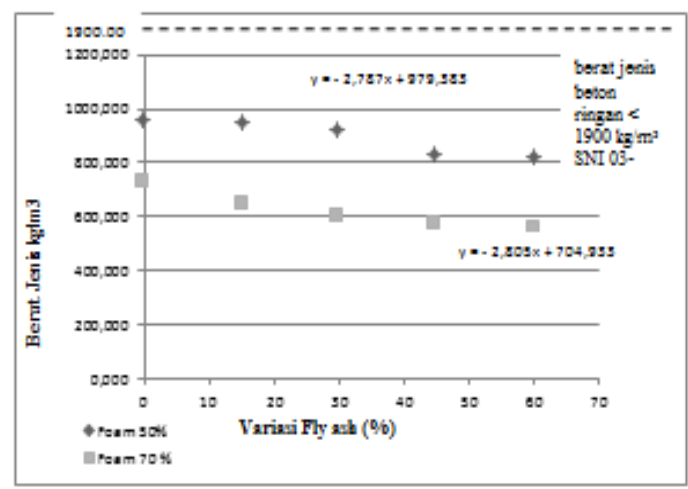

Gambar 5. Persyaratan Nilai Berat Jenis Bata Beton Ringan Berdasarkan SNI 03-2847-2002

penggunaan fly ash optimal pada foam $50 \%$ dan $70 \%$ untuk mencapai berat jenis minimal dengan variasi $0 \%, 15 \%, 30 \%, 45 \%$ dan $60 \%$ tidak didapatkan nilai optimal.

Penurunan berat jenis disebabkan berat jenis fly ash lebih rendah dari pasir dan semen. Berat jenis (specific gravity) fly ash yaitu 2,30 yaitu berkisar dari 2,1 sampai 3,0 umumnya lebih rendah dibandingkan dengan semen Portland (PC) yang mempunyai berat jenis 3,15 . Adanya perbedaan berat jenis ini disebabkan karena abu terbang lebih porous. (M.
Stefano, 2010). Dari hasil diatas disimpulkan bahwa semakin banyak penggunaan kadar fly ash maka berat jenis semakin menurun.

Dari gambar 5 di atas didapatkan nilai berat jenis bata beton ringan foam yang dihasilkan dari penggantian sebagian agregat halus dengan fly ash dan foam dalam penelitian ini berat jenis masuk dalam kategori bata beton ringan berdasarkan SNI 03 - 2847 - 2002. Nilai berat jenis yang masuk dalam kategori beton ringan yaitu $<1900$ $\mathrm{kg} / \mathrm{m}^{3}$.

3) Persentase Penggantian Fly ash Yang Menghasilkan Daya Serap Air Optimal Bata Beton Ringan Foam

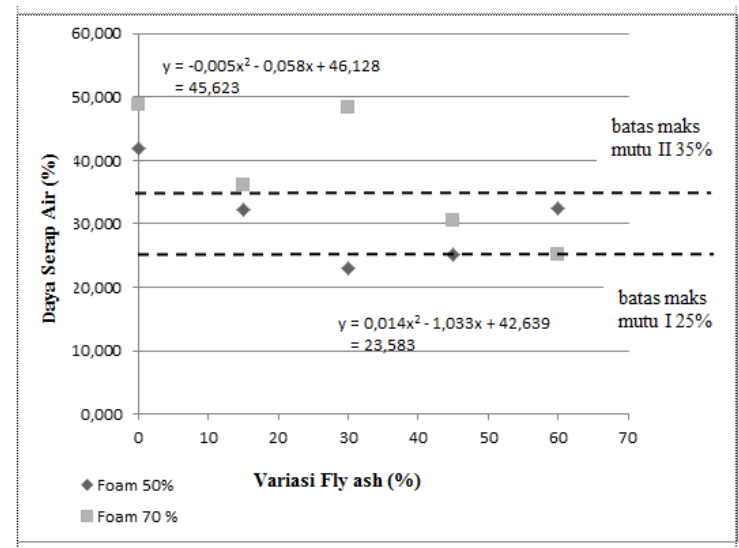

Gambar 6. Persyaratan Nilai Daya Serap Air Minimal Bata Beton Pejal Berdasarkan SNI 03-0349-1989

${ }^{1}$ Mahasiswa Program Studi Pendidikan Teknik Bangunan FKIP UNS.

${ }^{2}$ Pembimbing I Ir. Chundakus Habsya MS.Ars.

${ }^{3}$ Pembimbing II Sri Sumarni S.T., M.T. 
Penggunaan fly ash dan foam optimal untuk mencapai daya serap air minimal dengan variasi $0 \%, 15 \%$, $30 \%$, 45\% dan $60 \%$ dengan nilai optimal pada penambahan foam 50\% dan penggantian fly ash 28,52\% dengan daya serap air optimal $23,583 \%$ dan foam $70 \%$ dan penggantian fly ash 5,8\% dengan daya serap air optimal 45,623\%

Bertambahnya gelembung udara pada campuran menyebabkan kepadatan berkurang dan meningkatkan penyerapan air, pada kadar $50 \%$ foam dan $70 \%$ foam daya serap airnya lebih tinggi pada kadar $70 \%$ karena semakin banyak rongga gelembung maka semakin banyak penyerapan airnya. Dari hasil diatas disimpulkan bahwa proses hidrasi semen dengan fly ash membuat beton lebih padat tetapi dengan dipengaruhi pencampuran air tiap variasi fly ash yang berbeda-beda dan pencampuran foam mengakibatkan peningkatan dan penurunan daya serap air.

Dari gambar 6 di atas didapatkan persentase fly ash dan foam yang menghasilkan nilai daya serap air bata beton ringan foam yang memenuhi SNI 03 - 0349 - 1989. Terletak pada nilai optimal $23,583 \%$ dengan fly ash $28,52 \%$ dan foam $50 \%$.

\section{SIMPULAN DAN SARAN}

\section{a. Simpulan}

Berdasarkan hasil analisis data dan pembahasan dapat diambil kesimpulan sebagai berikut :

1) Penggunaan fly ash pada foam $50 \%$ memiliki pengaruh terhadap kuat tekan bata beton ringan foam sebesar $77,6 \%$ sedangkan sisanya dipengaruhi oleh variabel lain sedangkan pada foam $70 \%$ penggunaan fly ash memiliki pengaruh terhadap kuat tekan bata beton ringan foam sebesar $77,1 \%$ sedangkan sisanya dipengaruhi oleh variabel lain.

2) Penggunaan fly ash pada foam $50 \%$ memiliki pengaruh terhadap berat jenis bata beton ringan foam sebesar $92 \%$ sedangkan sisanya dipengaruhi oleh variabel lain sedangkan pada foam $70 \%$ penggunaan fly ash memiliki pengaruh terhadap berat jenis bata beton ringan foam sebesar $88,3 \%$

${ }^{1}$ Mahasiswa Program Studi Pendidikan Teknik Bangunan FKIP UNS.

${ }^{2}$ Pembimbing I Ir. Chundakus Habsya MS.Ars.

${ }^{3}$ Pembimbing II Sri Sumarni S.T., M.T. 
sedangkan sisanya dipengaruhi

oleh variabel lain.

3) Penggunaan fly ash pada foam $50 \%$ memiliki pengaruh terhadap daya serap air bata beton ringan foam sebesar $92,4 \%$ sedangkan sisanya dipengaruhi oleh variabel lain sedangkan pada foam $70 \%$ penggunaan fly ash memiliki pengaruh terhadap daya serap air bata beton ringan foam sebesar $43,3 \%$ sedangkan sisanya dipengaruhi oleh variabel lain.

4) Tidak didapatkan nilai kuat tekan bata beton ringan foam yang memenuhi SNI 03 - 0349 - 1989.

Dengan kuat tekan minimal 2,5 MPa.

5) Semua nilai berat jenis bata beton ringan foam yang dihasilkan memenuhi kategori berat jenis beton ringan berdasarkan SNI 03 $2847-2002$.

6) Nilai daya serap air yang memenuhi SNI 03 - 0349 - 1989 terdapat pada nilai optimal $23,583 \%$ pada variasi fly ash $28,52 \%$ dan variasi foam $50 \%$.

\section{b. Saran}

Berdasarkan hasil analisis data dan pembahasan dapat disarankan sebagi berikut :

1) Perlu ditinjau dari segi ekonomi dalam penelitin penggunaan fly ash dalam pemanfaatan pada bata beton ringan foam.

2) Perlu adanya pengembangan penelitian lebih lanjut mengenai bata beton ringan foam dengan perawatan beton ringan.

3) Perlu ditinjau kandungan zat kimia dari foam agent, zat adiktif (ADT) dan fly ash.

4) Perlu adanya pengembangan perhitungan mix design terutama pada pencampuran fly ash yang semakin banyak.

5) Pada penelitian selanjutnya untuk penggunaan variasi foam minimal menggunakan $50 \%$ dari kebutuhan bahan karena penambahan foam terlalu banyak berpengaruh pada kuat tekan dan daya serap air.

${ }^{1}$ Mahasiswa Program Studi Pendidikan Teknik Bangunan FKIP UNS.

${ }^{2}$ Pembimbing I Ir. Chundakus Habsya MS.Ars.

${ }^{3}$ Pembimbing II Sri Sumarni S.T., M.T. 


\section{DAFTAR PUSTAKA}

Anonim 1989. Bata Beton Untuk Pasangan Dinding. SNI 030349-1989.

Anonim 2002. Tata Cara Perhitungan Struktur Beton Untuk Bangunan Gedung. SNI 032847-2002.

Eko Hindaryanto Nugroho, (2010). Analisis Porositas Dan Permeabilitas Beton Dengan Bahan Tambah Fly ash Untuk Perkerasan Kaku (Rigid Pavement). Surakarta: Program Studi Teknik Sipil, Fakultas Teknik, Universitas Sebelas Maret Surakarta.

Hanizam Awang, Md Azree Othoman Mydin, dan Ahmad Farhan Roslan, (2012)

Microstructural Investigation Of Lightweight Foamed Concret Incorporating Various Additives. International Journal Of Academic Research.

Helmi Ardiansyah. (2004), Kajian Serapan Air Laut Pada Beton Ringan. Surakarta : Program Studi Teknik Sipil, Fakultas Teknik, Universitas Sebelas Maret Surakarta.

Krisbiyantoro, Bambang, (2005). Tinjauan Permeabilitas Dan Shringkage Beton Mutu Tinggi Dengan Bahan Tambah Mineral Metakoalin Dan Superplasticizer. Tugas Akhir. Jurusan Teknik Sipil, Fakultas
Teknik, Universitas Sebelas Maret Surakarta.

Lili Susmiati, (2015). Pengaruh pemanfaatan limbah fly ash terhadap kuat tekan, berat jenis dan daya serap air bata beton ringan foam sebagai Suplemen Materi Mata Kuliah Teknologi Beton. Tugas Akhir. Penangunan, FKIP, Universitas Sebelas Maret Surakarta.

M. Afaza, Muh, (2014). Pengaruh Penambahan Serat Polyethylene Pada Beton Ringan Dengan Teknologi Foam Terhadap Kuat Tekan, Kuat Tarik Belah Dan Modulus Elastisitas, Skripsi. Surakarta : Program Studi Teknik Sipil, Fakultas Teknik, Universitas Diponegoro.

Murdock, L. J dan Brook, K. M, (1986). Bahan Dan Praktek Beton. Terjemahan Stephanus Hindarko, Erlangga, Jakarta.

Stefano Munir, (2010). Penggunaan Bahan Pengisi Abu Terbang Dalam Industri Karet. Pusat Penelitian Dan Pengembangan Teknologi Mineral Dan Batubara.

Sumarno, (2010). Pemanfaatan Limbah Abu Terbang (fly ash) Batubara dan Kulit Kerang Sebagai Bahan Substitusi Semen Serta Limbah Beton Sebagai Pengganti Pasir

${ }^{1}$ Mahasiswa Program Studi Pendidikan Teknik Bangunan FKIP UNS.

${ }^{2}$ Pembimbing I Ir. Chundakus Habsya MS.Ars.

${ }^{3}$ Pembimbing II Sri Sumarni S.T., M.T. 
Dalam Pembuatan Bata Beton.

Medan: Tesis

${ }^{1}$ Mahasiswa Program Studi Pendidikan Teknik Bangunan FKIP UNS.

${ }^{2}$ Pembimbing I Ir. Chundakus Habsya MS.Ars.

${ }^{3}$ Pembimbing II Sri Sumarni S.T., M.T. 